\title{
GAO Report on NATO Enlargement: Albania and Croatia *
}

Joseph A. Christoff, et al.

\section{Background: NATO Enlargement}

The North Atlantic Treaty was signed on 4 April 1949 by twelve European and North American countries to provide collective defense against the emerging threat that the Soviet Union posed to the democracies of Western Europe. Since its inception, the Alliance's key objective has been to achieve a lasting peace in the North Atlantic area that is based on the common values of democracy, the rule of law, and individual liberty. Article 10 of the treaty permits the accession of additional European states if they are in a position to further the treaty's principles and contribute to North Atlantic security. While members must unanimously agree to any new country's accession, the treaty contains no explicit criteria that a country must meet to join the Alliance. NATO's invitations to countries to join the Alliance are political decisions based on the unanimous agreement of members.

At the 1999 summit meeting in Washington, D.C., NATO promulgated, among other things, the Membership Action Plan, to provide guidance and counseling to other NATO aspirants to facilitate their preparations for possible membership. The plan sets forth defense, budgetary, information security, legal, political, and economic goals for countries to work toward in order to enhance their readiness for membership. Essentially, NATO wants countries that are seeking to join the Alliance to:

- Be democracies that are based on the rule of law

- Have harmonious relations with neighboring countries and settle international disputes peacefully

- Provide and protect civil liberties, human rights, and minority rights

- Have an open market economy.

In addition, NATO wants countries to modernize and restructure their defense capabilities to be interoperable with NATO and therefore be able to contribute to NATO operations. To reach that goal, NATO would like countries to spend at least the equivalent of 2 percent of their gross domestic product (GDP) on defense development. Countries also need to implement NATO requirements for handling and securing NATO classified information and to be free from legal barriers that would prevent a country from deploying forces abroad or hosting foreign troops on their territory. Each

This report was presented to the relevant committees in the U.S. Congress by the U.S. Government Accountability Office (GAO) in September 2008. It was also presented to the Secretaries of State and Defense. Key staff in the GAO's International Affairs and Trade section who contributed to this report include Joseph A. Christoff, Jeffrey D. Phillips, M. Elizabeth Guran, Gezahegne Bekele, Lynn A. Cothern, Martin H. De Alteriis, Ernie E. Jackson, and Berel Spivack. The full text of the original report is available at http://www.gao.gov/ new.items/d081165r.pdf. 
country participating in the Membership Action Plan develops an annual plan of actions that it will pursue to achieve those goals. NATO reviews the plans and monitors aspirant member states' progress in implementing them, providing annual feedback to each country.

Since its inception, NATO has enlarged its membership five times as changing political and strategic circumstances have warranted. The first three occasions were linked to confrontation with the Communist bloc, particularly the Soviet Union, and were the result of pressing strategic and security needs. Turkey and Greece joined NATO in 1952 for strategic reasons, permitting NATO to shore up its southern flank to forestall Communist military action in Europe at the height of the Korean War. West Germany joined the Alliance in 1955 after agreeing to maintain extensive NATO forces on its territory and to place its national army within NATO's integrated command structure. With Spain's accession to membership in 1982, NATO gained better access to Spain's air and naval bases, while the newly democratized nation improved its chances of joining the European Economic Community.

A significantly different strategic environment marked the fourth and fifth rounds of enlargement. With the collapse of the Soviet Union, NATO's goal was to extend stability eastward. In 1994, NATO committed to enlarging its membership to include the newly democratic states of the former Communist bloc. As a result, Poland, Hungary, and the Czech Republic joined the Alliance in 1999. At its summit meeting in November 2002 in Prague, NATO invited seven additional countries to join as part of the fifth round of enlargement. Bulgaria, Estonia, Latvia, Lithuania, Romania, Slovakia, and Slovenia became members in March 2004. On 2 April 2008, Albania and Croatia were invited to begin accession talks with NATO, marking the start of the sixth round of enlargement. Figure 1 shows the two new invited countries and the current European members of NATO.

\section{Reports to Congress on New NATO Members}

The admission of new members to NATO requires ratification by two-thirds of the United States Senate. To ensure that Congress had sufficient information on the countries invited to join NATO, the Senate mandated in a 1999 resolution that the president provide Congress with information on countries seeking to join the Alliance before NATO made any decision on enlarging its membership. ${ }^{1}$ In particular, the president was required to assess how countries would further the principles of the North Atlantic Treaty, contribute to North Atlantic security, and affect U.S. national security interests. The president also was required to evaluate countries' eligibility for membership and estimate the military requirements and costs associated with a country's membership

Resolution of Ratification of the Protocols to the North Atlantic Treaty of 1949 on the accession of Poland, Hungary, and the Czech Republic, 144 Cong. Rec. S4217-20, 1998. 


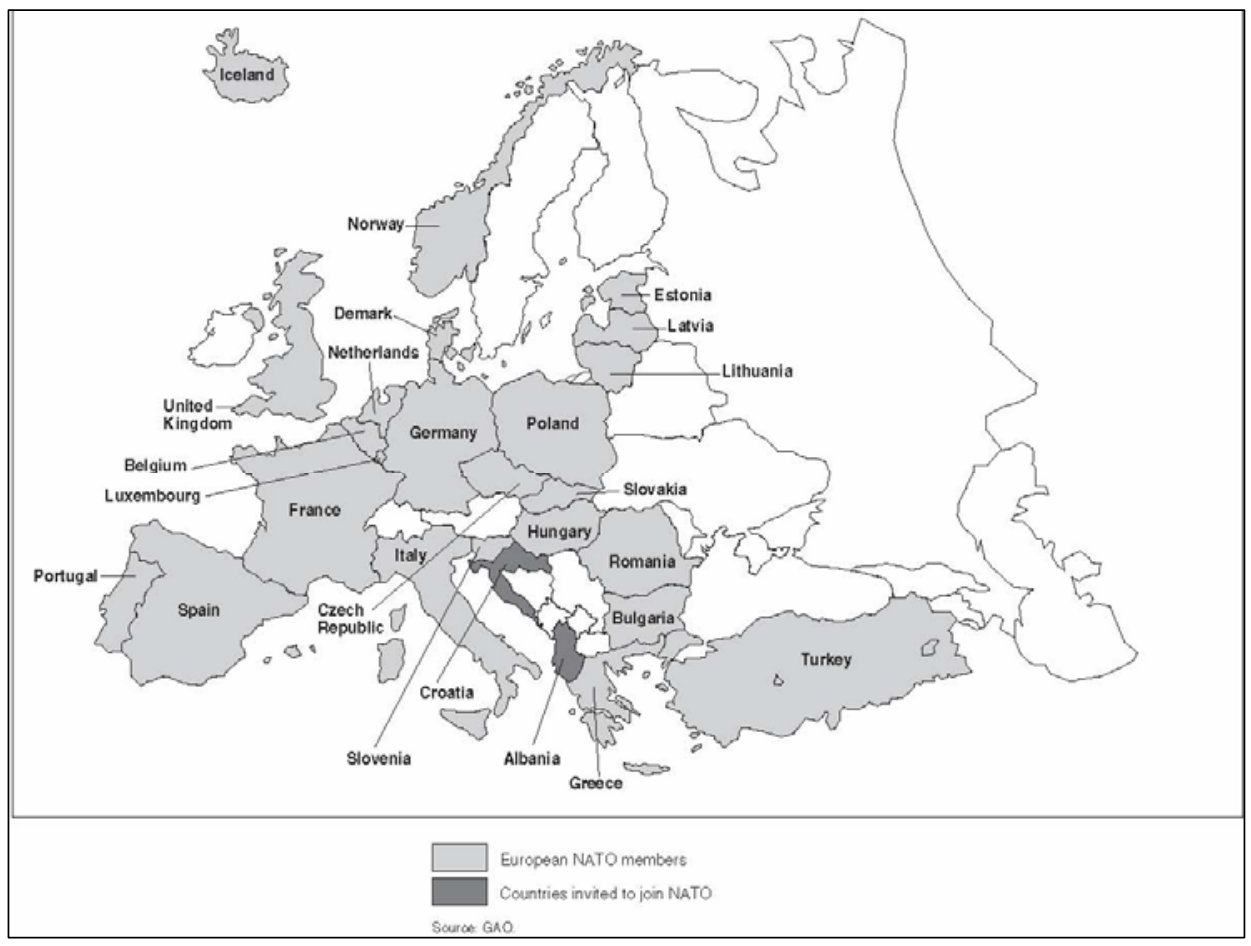

Figure 1: Countries Invited to Join NATO and Current European NATO Members.

for both NATO and U.S. budgets. ${ }^{2}$ President George W. Bush submitted a classified report on Albania and Croatia to Congress on 28 March 2008 to meet this requirement, in advance of the invitation to begin accession talks that was issued to the two countries on 2 April 2008.

Prior to signing any protocol to the North Atlantic Treaty on the accession of any country, the Senate mandated that the president provide Congress a classified and an unclassified report that provide updated information on the status of political, economic, defense, and related issues for the countries invited to join NATO in the recent round of enlargement discussions. ${ }^{3}$ In addition, these reports are to provide an assessment of the invited countries' likely impact on NATO's military effectiveness and an analysis of the ability of each invited country to fulfill the full range of financial bur-

2 Section 3(2)(E)(i) of the Senate Resolution of Ratification of the Protocols to the North Atlantic Treaty of 1949 on the Accession of Poland, Hungary, and the Czech Republic, 144 Cong. Rec. S4217-20, 1998.

3 Ibid., Section 3(2)(E)(ii). 
dens of NATO membership. President Bush submitted these reports on Albania and Croatia to Congress on 20 June 2008.

The Senate also requires that the U.S. Government Accountability Office-the investigative arm of Congress charged with examining matters relating to the receipt and payment of public funds - review and assess these reports. To fulfill our mandate, we determined whether the reports met the Senate's requirements, the information in the reports was complete, and the information in the reports was current.

To address our objectives, we reviewed information from an array of reports and analyses from the U.S. government, NATO, and the countries invited to join NATO, and discussed supporting documentation and methodologies used to prepare the reports with officials of the Departments of Defense and State. To address the first objective, we determined whether major issues in the mandates were addressed in the reports. To address whether information in the reports was complete, we assessed whether information in the president's reports concerning the aspirant countries was consistent with other U.S. government documents and data we collected from various sources, and whether key evidence that could affect the conclusions in the reports was included. To assess whether information in the reports was current, we assessed the supporting evidence to determine that it was dated within the past year and whether key events that have occurred that might alter the general information provided in the reports were included. This report addresses both the March and the June 2008 President's reports.

We conducted this performance audit from June 2008 through September 2008 in accordance with generally accepted government auditing standards. Those standards require that we plan and perform the audit to obtain sufficient, appropriate evidence to provide a reasonable basis for our findings and conclusions based on our audit objectives. We believe that the evidence obtained provides a reasonable basis for our findings and conclusions based on our audit objectives.

\section{Scope and Methodology}

We assessed the March and June 2008 classified reports and the June 2008 unclassified report and determined whether they addressed each of the mandated requirements. We assessed the completeness of the information by identifying whether all the major issues in the mandate were addressed, information in the reports and other U.S. government source documents were consistent, and key evidence that could affect the conclusions in the reports was included. However, due to our time frames, we did not compare the information with that contained in non-U.S. government sources. For the financial information, in our 2003 report, we determined whether the methodology and analytical criteria were clearly and fully described and whether the methodology provided a range of information that supported the conclusions.

To assess the currency of the 2008 reports, we determined whether the supporting evidence was current and whether any recent events cast doubt over the findings. For the purpose of this report, we defined current information as being from documents dated within the past twelve months or those most recently available. As part of our assessment, we also determined whether the president's reports addressed the recommendations that GAO made in its May 2003 report on NATO enlargement, and 
whether the unclassified report was generally consistent with the findings and conclusions identified in the classified reports.

We relied primarily on source documents from U.S. government agencies, including:

- The U.S. State Department's country background reports and annual reports assessing human rights practices, religious freedom, and trafficking in persons

- State Department reports and cable traffic concerning the aspirant countries

- Defense reform assessments prepared by the U.S. Department of Defense

- NATO documents concerning the aspirant countries' progress in meeting the goals identified in NATO's Membership Action Plan

- Country background reports from the Congressional Research Service

- Assessments and reports from the U.S. intelligence community.

We also reviewed reports from Amnesty International, Freedom House, and Human Rights Watch, and statistics from the Fraser Institute's and the Heritage Foundation and The Wall Street Journal's annual assessments of economic freedom. To assess the reliability of the statistical indexes in the Heritage Foundation/ Wall Street Journal and Fraser Institute's assessments, we reviewed the methodologies used to create them, and compared the indexes against each other. We determined that the indexes are useful tools for describing the relative levels of economic freedom for the nations included in them.

\section{Results in Brief}

President Bush's March and June 2008 reports on NATO enlargement respond to the congressionally mandated requirements and address all the key elements contained in the resolution concerning Albania's and Croatia's accession to NATO membership. For example, the reports discuss how Albania and Croatia would further the principles of NATO and contribute to the security of the North Atlantic area. They also discuss country eligibility for membership, including political, economic, defense, budgetary, information security, and legal issues - all goals of NATO's Membership Action Plan (MAP). ${ }^{4}$ Similarly, the president's reports respond to mandated requirements for estimates of the potential impacts of new members on both NATO and U.S. costs, and on NATO's shared costs.

The March 2008 report, submitted before the commencement of accession talks with Albania and Croatia, responded to the requirements for information identified in the congressional mandate. The June 2008 report updated the information in the March 2008 report and responded to additional information requirements concerning the aspi-

4 The MAP is a document intended to aid the preparations of those nations seeking to join the Alliance. Their participation in the MAP and in other NATO programs is intended to enable them to make significant strides in reforming their militaries and in enhancing the interoperability of their armed forces with NATO forces. 
rant countries' ability to meet the full range of the financial burdens of NATO membership and the aspirants' likely impact upon the military effectiveness of NATO.

The March 2008 report contained responses to the five requirements in the Senate's mandate, explaining:

- How these countries' accession would further the principles of the North Atlantic Treaty and contribute to North Atlantic security

- The countries' eligibility for membership based on the principles and criteria identified by NATO and the United States

- How these countries' accession would affect U.S. national security interests

- The common-funded military requirements and costs associated with integrating the countries into NATO and the impact on NATO's costs and members' shares of those costs

- The impact on U.S. defense and other budgets of integrating the country into NATO.

The June 2008 report on NATO enlargement responded to a specific Senate request to update the information contained in the March 2008 report and provide an analysis of the countries' ability to meet the full range of financial burdens of NATO membership and of their likely impact on NATO's military effectiveness.

The GAO analysis found the reports' information to be generally complete, and consistent with the data we collected from various sources, including agencies within the U.S. government and NATO. For example, the discussion of country eligibility for membership, including political, economic, defense, budgetary, information security, and legal issues and the status of their implementation is detailed and provides more information than reports submitted to Congress for previous rounds of NATO enlargement. The reports are also current, and address the relevant key events; in addition, there have been no recent developments that would call into question any of the reports' conclusions.

However, we found that the reports provide an incomplete explanation of why NATO lowered its estimate of certain enlargement costs for the two aspirants. We also found that the information concerning the countries' ability to fulfill the full range of financial burdens of NATO membership is incomplete. The June 2008 classified and unclassified reports provide little information concerning Albania and Croatia's ability to meet the full range of financial burdens of NATO membership, and do not identify the methodology used to support the conclusion that Albania and Croatia will be able to meet their financial obligations. We raised similar issues in our May 2003 report on 
the previous round of NATO enlargement. ${ }^{5}$ Without a complete understanding of the aspirant countries' ability to meet their financial obligations, NATO cannot be assured that goals in other areas will be achieved, since many of the goals rely on financial resources for their successful implementation. In addition, a key U.S. intelligence assessment that we reviewed differs from some of the conclusions in the president's reports concerning Albania and Croatia's ability to meet NATO financial obligations.

We are recommending that, for future NATO aspirants, the Secretary of Defense, in consultation with the Secretary of State, provide more complete information on the true costs of NATO enlargement. Such information would include the full range of the financial burdens of NATO membership for each country invited to join NATO in the future, each country's ability to assume those burdens, and the methodology used to reach the conclusions on this issue included the president's report, with explicit identification of the known and unknown costs involved.

\section{March 2008 Report}

The information in President Bush's report of March 2008 is generally complete. In addition to providing detailed information on the status of each aspirant under each required element, the report discusses challenges, progress, and future plans to address the elements. However, in response to the requirement to provide an analysis of the common-funded military requirements and costs associated with integrating the aspirant countries into NATO, we found that the report provides an incomplete explanation for why NATO lowered its estimate of certain enlargement costs for the two aspirants.

\section{Requirement 1: How a Country Would Further the Principles of the North Atlantic Treaty and Contribute to North Atlantic Security}

To assess how Albania and Croatia would further the principles of the North Atlantic Treaty and contribute to North Atlantic security, the president's March 2008 report provides a broad discussion of the countries' support of NATO principles, such as democracy, individual liberty, and the rule of law, and provides some examples of Albania's and Croatia's achievements in this area. For example, Albania remains committed to good neighborly relations and regional cooperation with its neighbors and has continued to be a steadfast ally in the global war on terrorism, offering substantial troop contributions to the operations in both Iraq and Afghanistan. The report states that Croatia respects and promotes the basic principles embodied in the North Atlantic Treaty. It has a stable, multiparty, democratic political system characterized by regular elections and a free and vibrant press. Croatian armed forces are under civilian control.

5 Government Accountability Office, "NATO Enlargement: Report Is Responsive to Senate Requirements, but Additional Information Could Be Useful," GAO-03-255 (Washington, D.C.: GAO, 15 November 2002); and "NATO Enlargement: Reports Are Responsive to Senate Requirements, but Analysis of Financial Burdens Is Incomplete," GAO-03-722 (Washington, D.C.: GAO, 5 May 2003). These reports are available at www.gao.gov/new.items/ d03255.pdf and www.gao.gov/new.items/d03722.pdf, respectively. 
In discussing the countries' potential impacts on North Atlantic security, the report describes their contributions to regional peace and stability - in particular, the ways in which Albania and Croatia address issues with neighboring countries and enhance regional cooperation. For example, Albania is a member of a Black Sea economic cooperation organization, which promotes economic liberty, cooperation, and trade development. Croatia enjoys good relations with neighboring countries and was elected to a non-permanent seat on the United Nations Security Council during the 2008-2009 period. To address the implications of these countries' membership for U.S. security, the report provides a detailed discussion of the contributions that Albania and Croatia have made and continue to make to NATO operations in Europe's Balkan region and their cooperation and assistance in the war on terrorism.

\section{Requirement 2: Country's Eligibility for NATO Membership Based on the Principles and Criteria Identified by NATO and the United States}

Most of the March 2008 report addresses the second information requirement of the mandate: to evaluate Albania's and Croatia's eligibility for NATO membership based on the principles identified by NATO and the criteria identified by the United States. The president's report presents a detailed discussion of the political, economic, defense, budgetary, information security, and legal goals that are part of each country's eligibility for membership. These goals emanate from NATO's Membership Action Plan. The report includes more detail on issues concerning membership eligibility than the reports submitted to Congress in 2002 and 2003, during the previous round of NATO enlargement. ${ }^{6}$ In addition to providing an update on the status of each MAP category, the report identifies the challenges faced by Albania and Croatia in meeting these goals and their plans to correct identified challenges. For example, the report notes that corruption in Albania remains a problem, but that the government has made additional arrests of high-level public officials and is making progress on convictions.

The political and economic goals addressed in NATO's MAP cover a broad spectrum, ranging from the implementation of democratic institutions, free and fair elections, the rule of law, judicial independence, and civil liberties to peaceful relations with bordering countries, peaceful settlement of international disputes, and protection of human rights and minority rights. The report's discussion of defense issues is extensive and describes Albania and Croatia's achievements in each of five key capability areas: deployability and mobility; sustainability and logistics; command and control; effective engagement; and survivability of forces and infrastructure. The report's discussion of budgetary issues focuses on the countries' commitments to defense spending as a percentage of gross domestic product, and defense procurement. Discussion of information security and legal issues focuses on the extent to which each coun-

6 One of the findings in the GAO's November 2002 report on NATO enlargement was that the president's report filed in advance of that enlargement round provided limited discussion of some eligibility issues, particularly concerning challenges facing the countries seeking NATO membership and what the countries were doing to address those challenges. See GAO-03-255. 
try has met or achieved NATO requirements. For information security, the report assesses the extent to which Albania and Croatia have implemented NATO requirements for personnel screening and the handling and storage of classified documents. Regarding legal issues, the report assesses whether the countries' constitution and/or laws provide any barriers to the deployment of their troops abroad in support of NATO operations, and discusses certain other legal issues.

The report also discusses the status of each country's economy, including economic growth. We also assembled additional information not contained in the president's reports that Congress may find useful on economic issues as they pertain to the two states - specifically, this information is a comparison of measures of economic freedom for NATO aspirants. These independent assessments of the level of economic development in Albania and Croatia are in line with the MAP commitment to promote stability through economic freedom. These assessments rely on two current studies that produce numerical measures of economic freedom - the Fraser Institute's 2007 Economic Freedom of the World report, which covers 141 countries for the year 2005, and the Heritage Foundation/ Wall Street Journal's 2008 report, Index of Economic Freedom, which covers 162 countries generally for the year ending mid-2007. ${ }^{7}$ Both indexes are revised annually and are based on numerous measures or indicators that are grouped together into areas of economic freedom.

To measure economic freedom, the Fraser Index studied twenty-three factorssome of which include multiple components - that fall into five categories ${ }^{8}$ :

- Size of government

- Legal structure and security of property rights

- Access to sound money

- Freedom to trade internationally

- Regulation of credit, labor, and business.

Each country's overall score for economic freedom is based on the average of its scores in each of these five areas. Scores range from zero to ten, with ten the highest degree of economic freedom.

To measure economic freedom, the Heritage Foundation/ Wall Street Journal index studied numerous economic variables that fall into ten broad categories of economic freedom ${ }^{9}$ :

7 The Fraser Institute is an independent Canadian economic, social research, and educational organization that works to raise the level of understanding about economic and social policy; an additional 72 institutions in 72 countries are co-publishers. The Heritage Foundation is a research and educational institute that promotes conservative public policies that are based on the principles of free enterprise, limited government, individual freedom, traditional American values, and a strong national defense.

8 For the Fraser Index, the key ingredients of economic freedom are personal choice, voluntary exchange, freedom to enter and compete, and protection of persons and their property. 
- Business freedom

- Trade freedom

- Government size

- Monetary freedom

- Investment freedom

- Financial freedom

- Fiscal freedom

- Property rights

- Freedom from corruption

- Labor freedom.

Each country's overall score for economic freedom is based on the average of its scores in each of these ten areas. The index scores countries from 0 to 100 , with 100 indicating an assessment of "most free."

Figure 2 below presents the ratings of countries by the Fraser Index and the Heritage Foundation/ Wall Street Journal index for the NATO applicants Albania and Croatia, each of the ten newer members, as well as each of the sixteen older members. The farther a country's location is toward the upper right of the graph, the higher its ratings of economic freedom. For example, considered together, the two indexes rate the United States followed by Canada then the United Kingdom as having the most economic freedom, and they appear farthest toward the upper right. Since all of the countries we are concerned with scored between five and nine on the Fraser Index and fifty and ninety on the Heritage Foundation/ Wall Street Journal index, we limited the graph to this region.

Both Albania and Croatia have low levels of economic freedom compared to most NATO members. Economic freedom in Albania is rated lower than all NATO members by the Fraser Index, but slightly greater than or equal to seven NATO members according to the Heritage Foundation/ Wall Street Journal index. The level of economic freedom in Croatia is rated slightly greater than or equal to that in three NATO members, according to the Fraser Index, but is lower than all NATO members according to the Heritage Foundation/ Wall Street Journal index.

\section{Requirement 3: Potential Effect of Albania's and Croatia's NATO Membership on the National Security Interests of the United States}

The March 2008 report provides generally complete information on Albania and Croatia's impact on U.S. national security interests by focusing primarily on the aspirant countries' participation in NATO-led and coalition operations, both within the region and outside of it. The report speculates on Albania and Croatia's continued capa-

9 The Heritage Foundation/ Wall Street Journal index defines economic freedom as the absence of government coercion or constraint on the production, distribution, or consumption of goods and services beyond the extent necessary for citizens to protect and maintain liberty. 


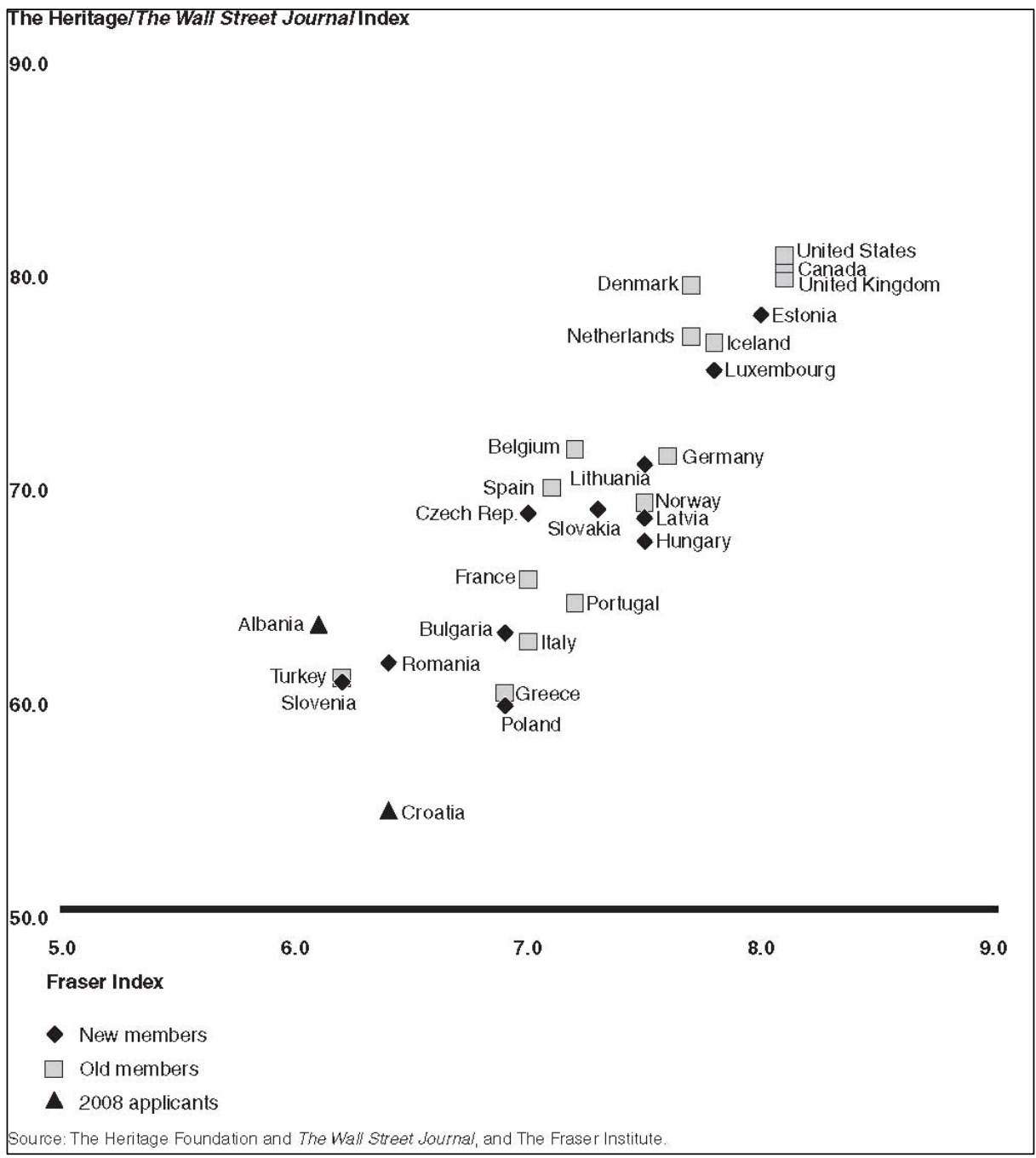

Figure 2: Indexes of Economic Freedom for NATO Members and Countries Seeking NATO Membership.

bility to provide support to coalition operations. For example, the report stated that Albania is building its niche military capabilities and is on its way to being fully interoperable with NATO forces. It stated that Croatia has demonstrated its willingness to contribute to common defense and security efforts, and that its membership in NATO would strengthen stability and security in the Balkans. 


\section{Requirement 4: An Analysis of the Common-Funded Military Requirements and Costs Associated with Integrating the Countries into NATO}

The president's report of March 2008 contains an incomplete analysis of the commonfunded military requirements and costs associated with integrating the aspirant countries into NATO. NATO estimates the common-funded enlargement costs for Albania and Croatia at USD 60 million each over a period of ten years or more post-accession. This is nearly half the estimate for a small aspirant country used during the previous round of enlargement. The report does not, however, provide an explicit explanation of how NATO reached this significantly reduced number, except to state that the decision to reduce the cost estimate was based on experience from the 2004 round of enlargement. Providing a fuller explanation of how NATO arrived at these cost figures would be useful, particularly in light of the uncertainties associated with the condition and capability of defense facilities in Albania and Croatia, as identified in the report. These uncertainties include the condition and capability of command, control, and communications networks, reception facilities, and air defense systems.

The report offers a generally complete explanation of the impact of enlargement on NATO's costs and members' shares of those costs. In its calculations, the report assumes that, given the relatively modest estimated costs of enlargement for Albania and Croatia, these costs would be funded largely within future common-funded budget ceilings. The report does not, however, explain how it determined that Albania and Croatia's enlargement costs will be "modest," particularly after identifying uncertainties associated with defense facilities and installations in these two countries. The report projects that any increases to the NATO Security Investment Program or military budget attributable to this round of enlargement would be minimal. On the basis of Albania and Croatia's projected cost shares, the report states that the U.S. cost share for each of the military common budgets would be reduced by approximately 0.08 percent.

\section{Requirement 5: Impact on U.S. Defense and Other Budgets of Integrating Al- bania and Croatia into NATO}

The report contains a generally complete discussion of the impact that the integration of Albania and Croatia into NATO would have on the U.S. defense budget and other U.S. budgets; the information provided generally supports the conclusions presented. According to the report, the costs can be accommodated within the likely future ceilings for the NATO Security Investment Program budget through a reordering of project priorities and extending the schedules for other projects. As a result, the report concludes that there will be minimal impact on DOD budget elements that provide the U.S. contribution to the NATO Security Investment Program and the military budget. For NATO's civil budget, the report estimates that in light of the smaller number and size of the current aspirants, the addition of Albania and Croatia will result in only a small increase in the civil budget, and possibly a modest addition to the construction costs for the new NATO headquarters building. Any increase would be partially offset by the new members' contributions to the civil budget and to the construction project. 


\section{June 2008 Report}

The information contained in President Bush's June 2008 report on NATO enlargement is generally complete. As required, the report updates the information contained in the March 2008 report on the integration of Albania and Croatia into NATO. The report then provides an analysis of the countries' ability to meet the full range of financial burdens of NATO membership, and the likely impact upon the military effectiveness of NATO. However, we found that the information and analysis concerning the countries' ability to fulfill the full range of financial burdens of NATO membership are incomplete. The report does not discuss the methodology used to reach conclusions about the countries' ability to meet financial obligations and does not include some costs. As mentioned above, without a full understanding of the aspirant countries' ability to meet their financial obligations, NATO cannot be assured that goals in other areas will be achieved if the countries lack sufficient financial resources. In addition, a key U.S. government information source differs from some of the conclusions in the President's reports concerning Albania and Croatia's ability to meet NATO financial obligations.

\section{Aspirant Countries’ Financial Qualifications}

The June 2008 classified and unclassified reports provide incomplete information on Albania and Croatia's ability to meet the full range of the financial burdens of NATO membership. The discussion in the reports is limited to identifying the countries' common-funded budget cost share and their 2008 defense budgets. ${ }^{10}$ On the basis of this information on the two governments' commitments to meet these costs, and the current rate of economic growth in both countries, the president's reports conclude that Albania and Croatia should be able to meet their financial obligations to NATO. The reports do not identify the methodology used to support the conclusions that Albania and Croatia should be able to meet their financial obligations. Without such a discussion of the methodology used, it is difficult to understand how the conclusions were derived.

In addition, the reports do not discuss all the costs associated with NATO membership. For example, becoming a NATO member also entails the cost of supporting country representation at NATO's facilities, such as its civilian and military headquarters in Belgium and its command posts in Europe, as identified in the GAO's 2003 report on NATO enlargement. ${ }^{11}$ As we reported, officials of the aspirant countries invited to join NATO during the previous round of enlargement stated that the costs of establishing and maintaining country representation at NATO facilities should be in-

10 For example, according to the June 2008 unclassified report, Albania's common-funded budget cost share, which includes the civil budget, the military budget, and the NATO Security Investment Program, is 0.0685 . Croatia's common-funded budget cost share is 0.2550 . Albania's approved 2008 defense budget is USD 268.9 million, which represents 2.01 percent of GDP. Croatia's approved 2008 defense budget is USD 1.14 billion, which is 1.8 percent of GDP.

11 GAO, "NATO Enlargement: Reports Are Responsive to Senate Requirements, but Analysis of Financial Burdens Is Incomplete," GAO-03-722. 
cluded in considerations of the costs of NATO membership. According to these officials, costs could vary between under 1 percent to as much as 2 percent of a country's annual defense budget. For countries with relatively small GDPs, this commitment of personnel and resources could be significant. By failing to discuss all of the costs associated with NATO membership, the reports do not provide comprehensive support for their conclusions on this issue.

In addition to not reporting the costs of country representation at NATO facilities, the reports also did not identify the costs of NATO membership as a percentage of the countries' total defense budgets. As discussed in our previous report on enlargement, the president's reports are not required to include this information, but these data would have provided useful background about the level of demand these costs will place on a country's total allocation of funds for defense, and hence its ability to fulfill the full range of NATO financial obligations.

\section{Impact on the Military Effectiveness of NATO}

We found that the information and description of the methodology for assessing the likely impact of Albania and Croatia on NATO's military effectiveness in the June 2008 reports were generally complete. The methodology laid out in the classified and unclassified reports assessed the soundness and feasibility of each country's defense reform plan, each country's support of U.S. and Allied actions through contributions to U.S. and NATO military operations, and the ability of each country to contribute specialized military capabilities to NATO once it becomes a member. The information provided supports the reports' conclusions about the likely impact of these countries' membership on NATO's military effectiveness.

The discussion of defense reform plans provides an understanding of the status of the countries' defense modernization efforts, their degree of military preparedness, and the extent to which NATO may need to assist the countries in accomplishing certain tasks. For example, the report points out that both Albania and Croatia have transformed their militaries from primarily territorial-based forces to militaries capable of deploying to Alliance and coalition operations, and that the United States and NATO have had numerous opportunities to assist Albania and Croatia in developing and implementing their defense reform plans. Identifying examples of how Albania and Croatia have participated in or contributed to NATO or other multilateral defense operations demonstrates how they can be expected to participate in NATO operations as members of the Alliance. Determining what kinds of specialized military capabilities the aspirants could provide to NATO illustrates how they will enhance NATO's preparations for future missions.

\section{Conclusion}

President Bush's reports to the Congress on the accession of Albania and Croatia to NATO membership responded to the Senate's requirements, providing information that was generally complete and current on each of the two aspirant states. While the discussion of country eligibility for membership is detailed and provides more infor- 
mation than reports submitted to Congress for previous rounds of NATO enlargement, we found that the information and methodology concerning the full range of the financial burdens of NATO membership, and the countries' ability to assume those burdens, was incomplete. We raised similar issues in our May 2003 report on NATO enlargement, but the President's 2008 reports do not address these issues. Without a more complete assessment of the financial burdens of NATO membership for Albania and Croatia, and their ability to assume those burdens, Congress would not have a fully accurate picture of the true cost of NATO enlargement.

\section{Recommendation for Executive Action}

To provide Congress with a complete picture of the cost of NATO enlargement, we recommend that the Secretary of Defense, in consultation with the Secretary of State, provide more complete information on the financial burdens of NATO enlargement for the president's reports to Congress. The needed information would include the full range of the financial burdens of NATO membership for each country invited to join in the future, each country's ability to assume those burdens, and the methodology used to reach conclusions on this issue in the reports, with explicit identification of the known and unknown costs involved. Given the short time frames for congressional action on this round of NATO enlargement, we would not expect such information to be provided for Albania and Croatia, but would expect that the Secretary implement our recommendation for all future NATO aspirant countries.

The GAO provided a copy of this report to the Departments of Defense and State for comment. DOD officials responded orally that the department concurred with the recommendation. They also provided additional information and documents on Albania and Croatia's ability to meet financial obligations that were not available at the time the reports were drafted. DOD officials said that they would add a more detailed discussion of the financial burdens of NATO membership for each country invited to join in the future. This would include more explicitly identifying both known and unknown costs and the methodology used to reach the report's conclusions. We modified the recommendation slightly to reflect DOD's comments. The State Department generally concurred with the report's findings and conclusions but had no comments on the recommendation. 
THE QUARTERLY JOURNAL

\section{Bibliography}

NATO Enlargement: Report Is Responsive to Senate Requirements, but Additional Information Could Be Useful. Washington, D.C. : Government Accountability Office (GAO), 2002.

NATO Enlargement: Reports Are Responsive to Senate Requirements, but Analysis of Financial Burdens Is Incomplete. Washington, D.C.: Government Accountability Office (GAO), 2003.

Resolution of Ratification of the Protocols to the North Atlantic Treaty of 1949 on the accession of Poland, Hungary, and the Czech Republic In Cong. Rec., 1998. 